\title{
Trump agenda threatens US legacy of science diplomacy
}

\section{Concerns mount that the new US president will sideline science's role in international relations.}

\section{Alexandra Witze}

27 January 2017

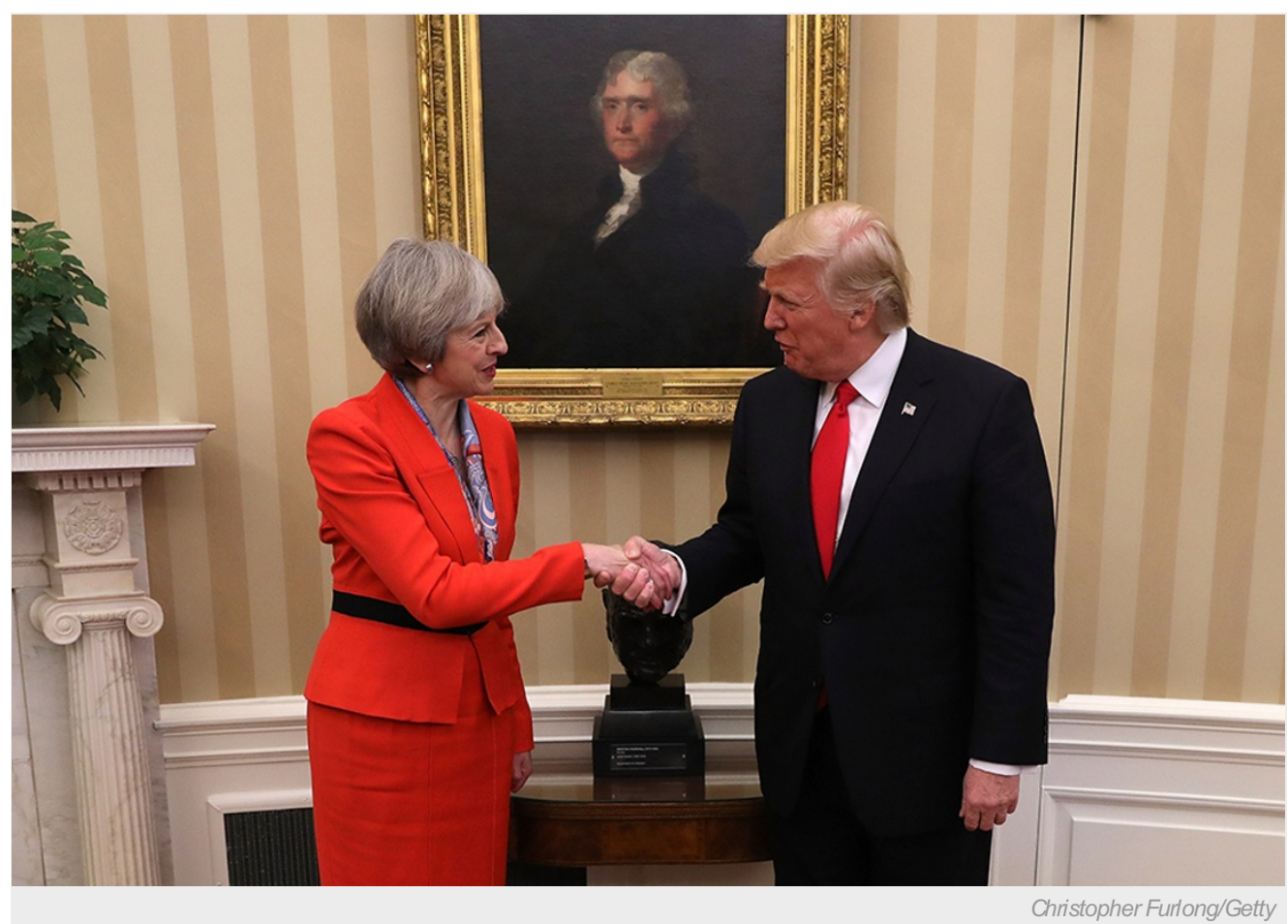

UK Prime Minister Theresa May meets with US President Donald Trump on 27 January.

A newly minted leader with no experience governing at home or establishing policy abroad now oversees the United States' vast diplomatic enterprise. US President Donald Trump has a deep bench of scientific and technical expertise to tap across multiple government agencies - but it is not clear that he will use it.

Science diplomats are watching warily to see whether the volatile new president will draw on the best available evidence when setting foreign policy. So far, his isolationist tendencies are winning: Trump is reportedly considering whether to pull the United States back from international organizations such as the United Nations. And he is drafting plans to ban immigration from a number of countries across the Middle East.

“Everybody's worried that we won't be in the room any more as a voice of reason advocating for evidence-based decision-making, for bringing the best and brightest to the table no matter where they come from or who they are," says Frances Colón, who until last week was the deputy science adviser at the US Department of State.

For decades, scientists have had a key role in informing US foreign policy, primarily through the state department. The American Association for the Advancement of Science (AAAS) began sending scientists to the department on yearlong placements in 1980, just before Ronald Reagan was elected. The department got its first permanent science adviser in 2000, late in Bill Clinton's presidency, a position that strengthened under George W. Bush when scientific exchanges were established with nations such as Iraq.

"We need scientists and engineers not just because of their technical expertise but because of their analytical nature, their ability to sift through a lot of different types of information and evidence and weigh them in a rational way," says Tom Wang, director of the AAAS Center for Science Diplomacy in Washington DC.

\section{Scientist to scientist}

The state department's current science adviser, geochemist Vaughan Turekian, is expected to stay on under the new secretary of state, presumed to be Trump's nominee Rex Tillerson. As the nation's top diplomat, Tillerson would be the US lead on international 
issues such as nuclear non-proliferation, disaster response, climate change and the oceans.

Tillerson is a member of the US National Academy of Engineering, elected during his tenure as head of the oil company ExxonMobil, where he also grappled with global issues such as public health. "He knows the importance of science," says Peter Hotez, a tropicaldisease expert at the Baylor College of Medicine in Houston, Texas, who has met Tillerson.

Science can be a starting point for traditionally estranged nations to open a dialogue, says William Colglazier, a physicist who was science adviser to the secretary of state from 2011 to 2014. "Even if other countries don't like our government, they still admire and want to interact with our universities, our research institutions and our high-tech companies."

For instance, years before Fidel Castro died, the Cuban government began working with the AAAS on scientific exchanges to study Caribbean-focused topics such as hurricane prediction and the spread of tropical diseases. The future of that programme is now in question, because Trump has suggested that he would reverse Barack Obama's loosening of US relations with Cuba.

"I firmly believe in the power of science diplomacy," says Jane Lubchenco, a marine biologist at Oregon State University in Corvallis who served as head of the National Oceanic and Atmospheric Administration and later as a 'science envoy' for the state department. "It has huge potential for sharing knowledge, for bringing goodwill, for resulting in tangible outcomes that can benefit people's lives and the opportunity to help build scientific capacity."

\section{Global view}

Lubchenco points to the envoy programme, which Obama created in 2009 as part of his early outreach to Muslim-majority countries. Eighteen top scientists have participated since then, in projects ranging from bolstering women in engineering in Nepal to establishing a vaccine production centre in Saudi Arabia. In her time as envoy, Lubchenco helped to set up working groups involving Chinese and US fisheries experts, as well as a programme headed by scientists in several African countries to track ocean acidification in the poorly monitored southwestern Indian Ocean.

US science diplomacy also happens outside of the state department. Physicist and former energy secretary Ernest Moniz was instrumental in negotiating the 2015 nuclear deal with Iran. The US Agency for International Development supports many research projects such as water management across the Middle East. Even former NASA administrator Charles Bolden travelled to Cairo in 2010, in a trip that backfired politically when critics charged that the space agency should be focused more on exploration than on improving international relations.

Trump has said that he supports high-tech businesses and investments that would keep the United States a global leader. But if he withdraws the country from the worldwide stage, other nations may soon surpass it in scientific and technical innovation, says Colón.

And isolationist stances like Trump's will further slow action on pressing international issues such as climate change, says Robert Patman, an expert in international relations at the University of Otago in Dunedin, New Zealand. "It remains to be seen whether science diplomacy can realize its full potential to make the world a better place," he says.

Nature | doi:10.1038/nature.2017.21382 